\title{
Fungal Lipase Production by Solid-State Fermentation
}

Luis Beltrán Ramos-Sánchez ${ }^{1 *}$, Mario César Cujilema-Quitio', Maria Caridad Julian-Ricardo', Jesus Cordova² and Patrick Fickers ${ }^{3,4}$

${ }^{1}$ Department of Chemical Engineering, University of Camagüey "Ignacio Agramonte Loynaz" Circunvalación norte, Km 5.5, 74650 Camagüey, Cuba

${ }^{2}$ Department of Chemistry, University of Guadalajara, Blvd. M. García Barragán 1421, CP 44430, Guadalajara, Jalisco, Mexico

${ }^{3}$ Biotechnology and Bioprocess Unit, Université libre de Bruxelles, Av. F.-D. Roosevelt, 50, CP165 / 61, 1050 Brussels, Belgium

${ }^{4}$ Microbial Processes and Interactions, Gembloux Agrobiotech, Univeristy of Liège, Passage des déportés, 2, 5030 Gembloux, Belgium

\begin{abstract}
Lipases are one of the most promising enzymes in the chemical and biopharmaceutical industries. Numerous applications have been reported including fine chemistry, detergents formulation and biodiesel synthesis. Lipases are commonly produced by a wide variety of yeasts and filamentous fungi in submerged fermentation or solid-state fermentation. Filamentous fungi and yeasts usually behave more efficiently in solid-state fermentation and show greater productivities when compared to submerged fermentation. Although filamentous fungi adequately growth in solid-state fermentation, there are some limitations for cultivating them by this process. Here, a review is made about lipase production in solid-state fermentation. This includes the analysis of solid-state fermentation as a promising technology, characterization of growth media and ambient factors such as moisture, $\mathrm{pH}$ and temperature.
\end{abstract}

Keywords: Lipase production; Solid-state fermentation; Yeast; Filamentous fungi; Bioreactor

\section{Introduction}

Lipases are serine hydrolases that catalyze in nature the hydrolysis of ester bonds of tri-, di- and mono- glycerides into fatty acids and glycerol. They are defined as triacylglycerol acyl hydrolases (E. C. 3.1.1.3) and differ from the closely related esterase's (E. C. 3.1.1.1) due to their ability to hydrolyze triglycerides at a lipid-water interface [1]. This phenomenon, the so-called "interfacial activation", was first proposed to distinguish lipases from esterases [2]. Unfortunately, this criterion was not sufficient to characterize the behavior of several lipases [3]. They were subsequently redefined as long chain fatty acid triglyceride hydrolases in apposition of esterases that are able to hydrolyze only short chain (i.e. less than 10 carbon atoms) fatty acid triglycerides.

The rising interest in lipase production mainly lies on the wide industrial applications of the enzyme [4-6]. They recognize a wide variety of substrates and may catalyze many different reactions, such as hydrolysis or synthesis of esters bonds, alcoholysis, aminolysis, peroxidations, epoxidations and interesterifications. The great number of recently published papers concerning different aspects of lipase production and applications also demonstrates the increasing importance of these enzymes [7].

Fungi and bacteria produce most lipases used in biotechnological applications. Filamentous fungi are an interesting source of lipases because they produce extracellular enzymes [8]. Lipases can be produced by Submerged Fermentation $(\mathrm{SmF})$ or by Solid-State Fermentation (SSF) processes, although fungi are better adapted than yeast and bacteria to grow on SSF [8]. Despite SmF is widely used in the enzyme industry and has advantages in process control and production yields, SSF represents an interesting alternative to produce industrial enzymes at lower costs $[8,9]$. SSF has many preferences to SmF for microbial enzyme production including: superior production yields and productivities, lower operating costs, less demands for asepsis control, cheaper fermentation media, higher oxygen distribution, fewer operational troubles, simpler equipments and control systems, lower energy consumption $[6,10]$.

The aim of present paper is to review literature concerning fungal lipase production by SSF in order to characterize different aspects that could be used to improve the process.

\section{Solid-state Fermentation as a Proper System for Fungal Culture}

SSF could be defined as a fermentation process in which microorganisms grow on a solid material, natural or synthetic, in absence or in a very limited amount of free liquid phase $[11,12]$ Bioreactors for this process could be operated in batch or in continuous mode (CSSF). In this later case, there is a flow of the solid phase within the reactor $[13,14]$. There are specific challenges to operate CSSF bioreactors that are not faced in classical continuous SmF. Consequently, CSSF processes are currently scarce in industry [14]. However, improved design procedures and sensors development promise a better future for CSSF at industrial scale.

SSF offers a quite different environment than SmF for cell growth and metabolism. In that regard, SSF is well adapted for yeasts and filamentous fungi cultivation since they can grow at low moisture content by contrast to bacteria [15]. Technologically, SSF presents several advantages compared to SmF [16]. Oxygen transfer limitations often encountered in SmF are eluded by a much more enlarged surface (external and/or internal) of the solid support for mass transfer [12,17]. In addition, cells and especially aerial hyphae are exposed directly to the gas phase, increasing significantly the overall oxygen transfer. Since SSF is performed at low water activity, it permits to prevent bacterial contaminations that require a high water activity to grow [18]. Moreover, the control of the optimal water activity in regards to a specific fungal species together with the utilization of an adequate cell inoculum, also permit to avoid or at least to reduce contamination by other fungal species. Beside these advantages, SSF also present several drawbacks such as heat generation by the cellular metabolic activity.

*Corresponding author: Luis Beltrán Ramos-Sanchez, Department of Chemical Engineering, University of Camagüey "Ignacio Agramonte Loynaz" Circunvalación norte, Km 5.5, 74650 Camagüey, Cuba, Tel: +53-32-261192; E-mail: luis.ramos@reduc.edu.cu

Received September 30, 2014; Accepted January 26, 2015; Published January 29, 2015

Citation: Ramos-Sanchez LB, Cujilema-Quitio MC, Julian-Ricardo MC, Cordova J, Fickers P (2015) Fungal Lipase Production by Solid-State Fermentation. J Bioprocess Biotech 5: 203 doi:10.4172/2155-9821.1000203

Copyright: (c) 2015 Ramos-Sanchez LB, et al. This is an open-access article distributed under the terms of the Creative Commons Attribution License, which permits unrestricted use, distribution, and reproduction in any medium, provided the original author and source are credited. 
One way to dissipate this heat consists in the mechanical agitation/ mixing of the solid medium [19]. However, this action could be harmful for filamentous fungi. It requires, thus a great compromise between cell survival and heat dissipation for process viability. This problem is not encountered for yeasts, thus offering a good opportunity for producing enzymes such as lipases with enhanced possibilities of competing in enzyme market.

\section{SSF versus SmF for Lipase Production}

SSF has many advantages over SmF for microbial enzyme production namely high yield and productivities, lower operating costs, low-cost fermentation media (raw biomass, agro industrial residues), higher oxygen distribution, fewer operational troubles, simpler equipment and control system $[10,20]$.

A comparative study on alkaline lipase production by a strain of Aspergillus fumigatus under SSF and SmF was made in which the maximum concentration of the enzyme was comparable in both cases [21]. However, lipase produced by SSF was stable over a period of 15 days whereas lipase production in $\mathrm{SmF}$ decreased from day 5. Other authors reported lipase produced by SSF to be $24 \%$ more active and $64 \%$ more thermally stable than lipase produced by SmF using a strain of Rhizopus homothallicus [22].

Although most of the industrial enzymes are currently produced by submerged fermentations, SSF appears a promising technology due to the advantages it offers, such as lower cost of production [12,23-25]. Compared to the cost of culture medium in SmF, SSF of agro-industrial solid wastes is inexpensive, and therefore this process is industrially and economically attractive [16,21]. Coradi et al. [20] reported a cost of lipase production by Trichoderma viride in SSF ten times lower than in SmF. For instance, total capital investment needed for a production scale of $100 \mathrm{~m}^{3}$ of lipase concentrate per year is $78 \%$ higher for SmF compared to SSF [17]. These results confirm the interesting potential of SSF for producing lipase at low cost.

\section{Industrial Applications of Lipases}

Lipases are essential components in the modern industrial process due to their ability to catalyze, depending on the thermodynamic conditions, hydrolysis reactions as well as synthesis reactions such as esterification and transesterification (Figure 1) [26]. Remarkably, in the last decade, yeast lipases were also applied in the manufacture of pharmaceuticals, pesticides, biosensors and in waste management [27]. Furthermore, the genes encoding lipases in Candida sp., Geotrichum sp., Trichosporon sp. and Yarrowia lipolytica have been cloned and overexpressed $[7,28]$. The most important lipase producers among yeasts used in industrial processes are Candida species namely C. antarctica, $C$. cylindracea, C. lipolytica and C. rugosa $[7,29,30]$. C. rugosa lipase is one of the enzymes most frequently used in bio-transformation and has the great advantage of being considered as safe for food applications. The crude enzyme extract contains at least five isoenzymes, denominated Lip1 to Lip5. Despite they share high sequence homology, they have different catalytic characteristics, substrate specificities and thermal stabilities [31]. CAL B from C. antartica is the second most studied yeast lipase, having several applications, such as synthesis of flavors and fragrance esters, surfactants, biodiesel, waxes, acylated flavonoids and modified glycerides as well as kinetic resolution of racemic esters and amines [32]. Its stability has also been improved using ionic liquids or no aqueous solvents for enzymatic synthesis [31]. Y. lipolytica lipase produces high value compounds, being used for bio-transformation of steroids and synthesis of pharmaceutical intermediates and fine chemicals [28]. Lipases from yeast are used in many different industrial processes as illustrated in the following sections.

C. antarctica lipases were used for esterification of free fatty acids in the absence of organic solvent and for transesterification of fatty acid methyl esters in hexane with isopropylidene glycerol [33]. Immobilized lipases from C. antartica, C. cylindracea and G. candidum were used for the esterification of functionalized phenols for synthesis of lipophilic antioxidants [34]. C. rugosa lipase is used by Nippon Oils \& Fats (Tokyo, Japan) for the preparation of highly pure unsaturated fatty acids (oleic, linoleic, linoleic, etc.) [35].

Large amounts of lipases, nearly 1000 tons per year, are used in the detergent industry for removal of oil-based stains [29]. For this purpose, lipases from C. cylindracea, Y. lipolytica and C. antarctica are preferred because they can operate at low temperatures and alkaline $\mathrm{pH}$, compared with bacterial and other fungal lipases [36,37]. Miyoshi Yushi, a company in Nagoya (Japan), produces sizable amounts of soap through lipase-based hydrolysis of oils and fats with C. rugosa lipase [35]. Enzymatic synthesis of surfactants has been carried out at moderate temperatures $\left(60-80^{\circ} \mathrm{C}\right)$ with excellent regioselectivity. Unichem International (USA) has manufactured isopropyl myristate, isopropyl palmitate and 2-ethyl palmitate, as emollient for personal care products using C. cylindracea lipase [38].

Lipases are used for flavor development and improving quality of foods. C. parapsilosis and C. antarctica lipases were used to synthesize hydroxamic acids, a food additive, and short chain flavor thioester, respectively. Additionally, C. rugosa lipase was used in the cheese manufacture [27]. The flavor development in concentrated milk and creams by microbial lipases was investigated, finding that each lipase developed a characteristic flavor. C. rugosa lipases were found as the most suitable for this purpose [39]. Several structural lipids were synthesized by yeast lipases and included in infant formula and nutraceuticals $[29,30]$. C. antarctica lipase is employed as a robust biocatalyst for esterification reactions, obtaining high conversions of flavoring esters of short-chain [40]. C. cylindracea lipase is used in bakery products manufacturing [41].

Biocatalytic processes are used to prepare chiral intermediates for pharmaceuticals. (S)[1-(acetoxyl)-4-(3-phenyl) butyl] phosphonic acid diethyl ester, a key chiral intermediate required for chemical synthesis of BMS-188494 (an anticholesterol drug) was prepared by stereoselective acetylation of racemic [1- (hydroxy)-4-(3-phenyl) butyl] phosphonic acid diethyl ester using Geotrichum candidum lipase [42]. CAL-B lipase was used for the enzymatic resolution of a racemic mixture of 2-pentanol, a key chiral intermediate required for synthesis of anti-Alzheimer's drugs [42]. C. cylindracea lipase was applied to the resolution of 2-bromopropionic acids and 2-cloropropionic acids which are starting materials for the synthesis of phenoxy propionic herbicides [43]. C. cylindracea and C. antartica lipases have been used to resolve the enantiomers of flurbiprofen, naproxen, ibuprofen, suprofen and baclofen [43]. Both enzymes were successfully used to synthesize lobucavir, hepatitis B antiviral and ribavarin antiviral [44]. These lipases are also suitable for transesterification reactions, displaying both wide substrate specificity and regiospecificity [45].

Croda Universal Ltd. (Sweden) uses C. cylindracea lipase to synthesize wax esters (esters of fatty acids and fatty alcohols) as additives for personal care products. According to the manufacturer, the overall production cost is slightly higher than that of the conventional method, however the cost is justified by the improved quality of the final product [42]. C. rugosa lipase was selected to hydrolyze triacylglycerol for clinical 
a)<smiles>[R]C(=O)OCC(COC([R])=O)OC([R])=O</smiles>

b)

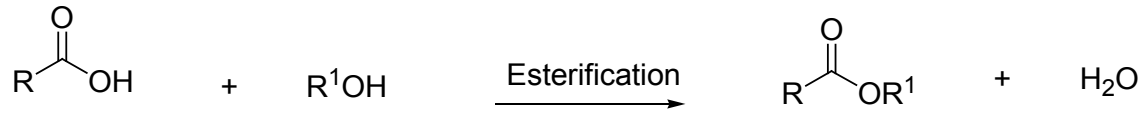

c)<smiles>[R]C(=O)O[Na]</smiles>

d)

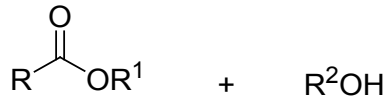

e)<smiles>[R]NN[R]</smiles>

g)<smiles>[R]OC([R])=O</smiles><smiles>[R]C(=O)O</smiles>
$\mathrm{R}^{2} \mathrm{COOR}^{1}$<smiles>[R]OC([R])=O</smiles>
$+$ $\mathrm{R}^{1} \mathrm{OH}$ Aminolysis<smiles>[R]NC([R])=O</smiles>
$\mathrm{R}^{1} \mathrm{OH}$

Thiolysis<smiles>[R]C([R])=O</smiles>
$\mathrm{R}^{1} \mathrm{OH}$

Figure 1: Reactions catalyzed by lipases. a) hydrolysis, b) esterification, c) acidolysis, d) alcoholysis, e) aminolysis, f) thiolysis, g) interesterifications

lipid analysis and developed as a biosensor $[38,43]$. C. rugosa lipase was also used to synthesize lovastatin, a drug lowing serum cholesterol level. The asymmetric hydrolysis of 3-phenylglycidic acid ester, which is a key intermediate in the synthesis of diltiazem hydrochloride, a coronary vasodilator, was carried out with $S$. marcescens lipase [46].

Lipases from different sources are able to catalyze biodiesel synthesis but those from C. antarctica and C. rugosa are the most used [45]. The Novozym 435 (CAL-B) lipase is able to convert at high yield used olive oil which contained high levels of free fatty acids and water content into biodiesel [45]. Simple alkyl ester derivatives of restaurant grease waste were prepared using immobilized lipases from Thermomyces lanuginosus and C. antarctica [47].

Lipases are utilized in activated sludge and other aerobic waste processes, where thin layers of fats must be continuously removed to allow oxygenation. Effective breakdown of solids, clearing and prevention of fat blockage or filming in waste systems are important in many industrial operations such as degradation of organic debris using a commercial mixture of lipase, cellulase, protease and amylase or sewage treatment, cleaning of holding tanks, septic tanks, grease traps. C. rugosa lipase is a good option to hydrolyze residual fats [37]. C. rugosa lipase was also used by Nippon Paper Industry to hydrolyze $90 \%$ of wood triglycerides as a pitch control method [43,48].

\section{Regulation of Lipase Production Concerning the Medium Composition}

Yields in lipase synthesis in SSF vary according the strain, the growth medium (solid support), culture medium (carbon and nitrogen sources) and cultivation conditions ( $\mathrm{pH}$, temperature and moisture). The main important lipases from filamentous fungi produced in SSF belong to the genera Aspergillus, Rhizopus and Penicillium while those from yeast origin belong to Candida and Yarrowia (Table 1). Most of the lipases produced by yeast and filamentous fungi are extracellular and their production is modulated by the culture conditions. Expression of lipase encoding genes is regulated by the nutrients from the culture medium and/or by the solid substrate used. Lipids such as triglycerides, fatty acid or long chain fatty acid esters are requested for high lipase production yields. Oleic acid (cis-9-Octadecenoic acid) was reported as the most suitable inducer for the production of the main extracellular Lip2p lipase in Y. lipolytica [51,52]. However, pure oleic acid is not convenient for the development of industrial processes owing to its excessive cost. With the aim of developing a cost-friendly process, different oleic acid esters and triglycerides have been tested for their ability to support lipase synthesis. Olive oil, mainly constituted by triolein as the main triglyceride, and methyloleate led to lipase activities equal to 1130 and $1190 \mathrm{U} \mathrm{ml}^{-1}$, respectively [53]. These results are in the range of that obtained with pure oleic acid (i.e. $1045 \mathrm{U} \mathrm{ml}^{-1}$ ). By contrast, ethyloleate led to a significant decrease of lipase production (195 $\mathrm{U} \mathrm{ml}^{-1}$ ). Expression of the $y l L I P 2$ lipase-encoding gene, and thus Lip2p synthesis appeared also to be markedly influenced by oleic acid concentration [51]. By contrast, carbon sources such as glucose and glycerol were found to repress lipase production [54].

Nitrogen sources used to supplement the culture medium also greatly influence lipases production. Various mineral and organic nitrogen sources were tested for their capacity to support cell growth and lipase production [51]. Mineral nitrogen such as ammonium chloride 


\begin{tabular}{|c|c|c|c|}
\hline Strain & Solid support / substrate & Lipase activity & References \\
\hline \multicolumn{4}{|l|}{ Yeast } \\
\hline Candida rugosa & $\begin{array}{l}\text { Coconut oil cake } \\
\text { Sesame oil cake } \\
\text { Groundnut oil cake } \\
\text { Rice Bran }\end{array}$ & $\begin{array}{l}88 \cup^{-1} \\
32 \mathrm{Ul}^{-1} \\
57 \mathrm{U} \mathrm{ml}^{-1} \\
37 \mathrm{U} \mathrm{g}^{-1}\end{array}$ & $\begin{array}{l}{[65]} \\
{[85]} \\
{[85]} \\
{[80]}\end{array}$ \\
\hline Yarrowia lipolytica & $\begin{array}{l}\text { Sugarcane bagasse/wheat bran } \\
\text { Palm kernal cake }\end{array}$ & $\begin{array}{l}9 \cup g^{-1} \\
19 \mathrm{Ug}^{-1}\end{array}$ & $\begin{array}{l}{[90]} \\
{[84]}\end{array}$ \\
\hline \multicolumn{4}{|l|}{ Mold } \\
\hline Aspergillus niger & $\begin{array}{c}\text { Wheat bran } \\
\text { Wheat bran/oleic acid }\end{array}$ & $\begin{array}{l}650 \mathrm{U} \mathrm{g}^{-1} \\
49 \mathrm{U} \mathrm{g}^{-1}\end{array}$ & $\begin{array}{c}{[50]} \\
{[6]}\end{array}$ \\
\hline Aspergillus fumigatus & Defatted rice bran & $9 \mathrm{U} \mathrm{ml}^{-1}$ & [21] \\
\hline Aspergillus carneu & Sunflower & $13 \mathrm{Ug}^{-1}$ & [69] \\
\hline Rhizopus homothalicus & Sugarcane bagasse/olive cake & $43 \mathrm{U} \mathrm{ml}^{-1}$ & [81] \\
\hline Rhizopus oryzae & Sugarcane bagasse & $215 \mathrm{U} \mathrm{g}^{-1}$ & {$[16]$} \\
\hline Penicillium brevicompactum & $\begin{array}{l}\text { Babassu oil cake } \\
\text { Castor meal }\end{array}$ & $\begin{array}{l}49 \mathrm{U} \mathrm{g}^{-1} \\
88 \mathrm{U} \mathrm{g}^{-1}\end{array}$ & $\begin{array}{l}{[75]} \\
{[75]}\end{array}$ \\
\hline Penicillium restrictum & Babassu oil cake & $30 \mathrm{U} \mathrm{g}^{-1}$ & [74] \\
\hline Pennicillium $s p$ & Soybean meal & $140 \mathrm{U} \mathrm{g}^{-1}$ & [79] \\
\hline Rhizomucor pusillus & $\begin{array}{c}\text { Sugarcane bagasse/olive cake } \\
\text { Sugarcane bagasse }\end{array}$ & $\begin{array}{l}21 \mathrm{U} \mathrm{ml}^{-1} \\
5 \mathrm{U} \mathrm{g}^{-1}\end{array}$ & $\begin{array}{l}{[81]} \\
{[81]}\end{array}$ \\
\hline Rhizomucor rhizopodiformis & Sugarcane bagasse & $3 \mathrm{Ug}^{-1}$ & [81] \\
\hline
\end{tabular}

Table 1: Strain used in solid-state fermentation for lipase production. Lipase activity, unless stated otherwise, is expressed in unit per gram of dry solid support

or ammonium sulfate had no influence on either cell growth or lipase production. By contrast, a significant increase in lipase productivity was observed upon addition of organic nitrogen sources such as urea or casein hydrolysates. For instance, tryptone N1 (Organotechnie, La Courneuve, France) allowed a 166-fold increased lipase production compared to the non-supplemented medium. However, cultures in the presence of casamino acid, which result from a complete hydrolysis of casein, led to a low lipolytic activity. These results suggest that specific peptides constituting tryptone N1 could regulate lipase production [51]. This hypothesis was confirmed by testing separately different tryptone constituting peptides [55].

Recently, lipase production by Y. lipolytica in SSF using different agro-industrial residues was reported [56]. When soybean cake and its sludge were used, lipase activity reached $139 \mathrm{Ug}^{-1}$ after $14 \mathrm{~h}$ of fermentation whereas a lipase activity of $102 \mathrm{Ug}^{-1}$ was obtained after 28 $\mathrm{h}$ of fermentation when cottonseed cake was used as substrate without any supplement [56].

C. rugosa is able to produce three lipase isoenzymes, namely Lip1, Lip2 and Lip3. Their production is modulated in yield (enzymatic activity) and in quality (isoenzyme synthesis) by the culture conditions and medium composition. Glucose and glycerol repress lipase synthesis [57,58] whereas oleic acid, ester of oleic acid and olive oil enhance its synthesis [59]. At low concentrations, oleic acid seems to favor the synthesis and secretion of Lip2 and Lip3 lipase isoenzymes while Lip1 is only produced at high oleic acid concentration [60]. Lipase production was also reported in the presence of carbon sources such as sterols [61], hexadecane [61], carboxylic acids [59], vegetable oils [62] and dodecanol [63]. By contrast, no lipase production could be detected in the presence of alkane, despite this carbon source could support cell growth [58]. Corn steep liquor [64] was reported has a suitable nitrogen source for lipase production in C. rugosa together with urea [65] and peptone [66].

In SSF, lipase production is also modulated by the solid support/ medium used. Twelve solid substrates were tested in regard to lipase production in Aspergillus niger [67]. The highest lipase production was obtained with wheat bran $\left(198 \mathrm{Ug}^{-1}\right)$ and gingelly oil cake (169 Ug $\left.{ }^{1}\right)$. Addition of various nitrogen sources, carbohydrates and inducers to the substrate did not yielded to any significant increase of lipase synthesis. This demonstrates that in some cases, the solid substrate used is sufficient to support both cell growth and lipase production at high yield. Other authors reported that lipase synthesis by $A$. niger is enhanced in the presence of Tween 80 , soybean meal, urea and ammonium sulfate [68]. Lipase production in Aspergillus carneus was improved by a response surface approach using a one-at-a-time method $[3,69]$. The highest lipase productions were obtained in a medium composed of sunflower oil (1\%), glucose $(0.8 \%)$ and peptone $(0.8 \%)$. Similarly, the highest lipases production by Aspergillus terrus was obtained in a medium containing corn oil (2\%) and casein hydrolysate (0.1\%) [70]. The presence of calcium and magnesium ions enhanced lipase secretion [70]. Beside this, the highest lipase production by Aspergillus oryzae was obtained in a medium containing sunflower oil (3\%), glucose (2\%), yeast extract (1\%) and polypeptone (2\%) [71]. Similarly to Aspergillus sp, lipases synthesis by Rhizopus arrhizus is inhibited by glucose whereas a 2.5 fold increase in lipase production was obtained in the presence of corn oil used as inducer [72]. For Rhizopus oryzae growing on rice straw, olive oil (1.38\%) and soybean meal (1.27\%) are the optimal inducer and nitrogen source, respectively [73]. In these conditions, lipase production reached $59 \mathrm{Ug}^{-1}$. Lipase production by Penicillium restrictum in SSF was investigated on solid waste from the babassu oil industry. The medium was supplemented with peptone, olive oil or starch at different $\mathrm{C} / \mathrm{N}$ ratios. The highest lipase production was obtained with $1 \%$ of peptone enrichment $(\mathrm{C} / \mathrm{N}$ ratio of $\left.11.7,28 \mathrm{Ug}^{-1}\right)$ and with $2 \%$ olive oil enrichment $(\mathrm{C} / \mathrm{N}$ ratio of $\left.14.1,30 \mathrm{Ug}^{-1}\right)$ [74]. Molasses, urea and soybean oil concentrations as well as moisture content were tested for lipase production by Penicillium brevicompactum in SSF using babassu cake and castor meal as solid support [75]. For babassu cake, the highest lipase activity was obtained for a moisture content of $70 \%$ and $2 \%$ of soybean oil. This result was in accordance with those obtained for Burkholderia sp. using olive oil [76]. Beside this, lipase production by Penicillium citrinum was investigated on medium containing $1 \%$ groundnut-oil refinery residues as carbon source and various nitrogen contents. Ammonium chloride $(0.75 \%)$ was found to be the best nitrogen source compared to ammonium sulfate and urea. This latter yielded to a decrease of lipase synthesis by 85\% [77]. Compared to oleic acid, a two-fold increased lipase activity 
was obtained in the presence of this oil refinery residue due to its high carbohydrates content (35\%). Production of lipase by Penicillium simplicissium in SSF, using babassu cake as the basal medium, was investigated in the presence of olive oil, sugarcane molasses, corn steep liquor and yeast extract. Olive oil and corn steep liquor were found the most suited carbon and nitrogen sources for lipase synthesis [78]. Rigo et al. [79] reported that the medium supplementations with urea and soybean oil significantly increased lipase production by Penicillium sp. grown in SSF with soybean meal as the solid substrate [79]. All these data highlight clearly that production of fungal lipase depends of several factors such as the solid substrate used and the nature of the carbon and nitrogen sources used as supplement. Additionally, the moisture content, $\mathrm{pH}$ and temperature should also be taken into account for process optimization.

\section{Solid Media, Solid Support and Ambient Factors used for Lipase Production}

As stated above, one of the main characteristics of SSF is the utilization of solid substrates as a support for cell growth. For some applications, these solid supports are also the only sources of carbon and nitrogen available to sustain microbial growth. These supports could be from artificial nature or of biological origin. In the recent years, considerable researches have been carried out using agricultural wastes, which are renewable and abundantly available, to produce value-added products by SSF. Utilization of agro-industrial wastes provides alternative substrates and may help to solve pollution problems. The nature of the substrate is the most important factor affecting fermentative processes.

The choice of a substrate depends on several factors, mainly related to their cost and availability but also to the nature of the compound to produce (enzyme, metabolite, biomass) [7]. Many substrates such as rice bran [80], coconut oil cake [65], olive cake and sugar cane bagasse [81], gingelly oil cake [67], babassu oil cake [74], wheat bran [82], Jatropha curcas seed cake [83], niger seed oil cake [84], palm kernal cake [84], groundnut oil cake [85] and mustard oil cake [86] have been used successfully for lipase production. The most important process parameters that have been investigated and optimized up to now are the incubation time, inoculum age, inoculum size, initial moisture content, nature and concentration of carbon and nitrogen sources as well as the $\mathrm{C} / \mathrm{N}$ ratio of the medium [87].

The importance of water content in SSF has long been recognized $[88,89]$. This could be viewed in terms of moisture or water activity. Moisture represents the fraction of water present in the medium while water activity represents the fraction of free water in available to microorganisms [90]. The moisture content of the solid substrate used can vary due to liquid evaporation, microbial metabolism and by the water-binding characteristics of the substrate [12]. This moisture content has a significant impact on microbial growth and metabolic activities, including lipase production [90]. In general, the moisture content used in SSF processes vary between 30 and $85 \%$ [91]. The influence of initial moisture content on lipase production by $Y$. lipolytica from niger seed oil cake was studied in the range of 50 to $100 \%(\mathrm{v} / \mathrm{w})$ [84]. An initial moisture content of $60 \%(\mathrm{v} / \mathrm{w})$ lead to the maximal value of lipase production $\left(18.5 \mathrm{Ug}^{-1}\right)$. At higher moisture contents, the lower lipase production observed could be due to a decrease of the substrate porosity and hence in a decrease of the gaseous exchange that lead to suboptimal conditions for cell growth and enzyme production. By contrast, low moisture content could lead to a reduction of the nutrients solubility and availability, a reduced degree of swelling and a higher water tension. For the production of lipase in SSF by Y. lipolytica from mustard oil cake, the maximum lipase activity was obtained at $50 \% \mathrm{v} / \mathrm{w}$ initial moisture content [86]. The effect of initial moisture content from 40 to $90 \%$ (v/w) on lipase production of C. rugosa using groundnut oil cake was investigated. A moisture content of $60 \% \mathrm{v} / \mathrm{w}$ was reported as the optimal value $[85,86]$. Although moisture content is a commonly used factor to optimize growth medium, it is known that microorganisms are more sensitive and specific to water activity [88].

Another important parameter to consider in SSF is the $\mathrm{pH}$ variation during the process since this latter is difficult to control due to the heterogeneity of the system. During cell growth, $\mathrm{pH}$ variation is mainly caused by the secretion of organic acids or by the assimilation of nitrogen sources such as ammonium, nitrate or urea. Each microorganism has an optimal $\mathrm{pH}$ range for growth and metabolic activity, including lipase production and secretion. However, they are able to grow in a wide $\mathrm{pH}$ range from 2.5 to 8.5 . This versatility of fungi in regards to $\mathrm{pH}$ can be beneficially exploited to prevent or minimize bacterial contaminations [91]. Lipase production has been investigated for different $\mathrm{pH}$ values ranging from 3.0 to 9.0. The maximum lipase production has been observed between $\mathrm{pH} 6.0$ and 7.0 [5].

Temperature control is also an important factor to consider. During SSF, it is difficult to remove the excess of heat generated by the cellular metabolism, mainly due to the low thermal conductivity of the solid medium [15]. In some cases, this heat acccumulates within the solid medium, causing a decrease in microbial growth and even, in some cases cell death. The temperature at the center of the fermenting solid medium could be higher up to twenty degrees than the incubation temperature [92]. An airflow through the system is often applied to dissipate metabolic heat from the solid medium and also to supply the oxygen requirements for cultures [92]. Remarkably, optimal temperatures for lipase production have been reported in the range of 28 to $45^{\circ} \mathrm{C}[12,86]$.

\section{Lipase Production using different SSF Bioreactors}

Lipase production by SSF has been mainly performed in tray bioreactors (TB) and packed-bed bioreactor (PBB). TB are the simplest design for SSF $[93,94]$. They can be considered as a modification of a column bioreactor in which the height of the bed is short enough to prevent temperature profiles to form in the axial direction. Tray bioreactors consist of a chamber where controlled air (flow, temperature and relative humidity) is circulated around a number of trays (Figure 2). Each tray contains a layer of solid substrate, typically between 5 and

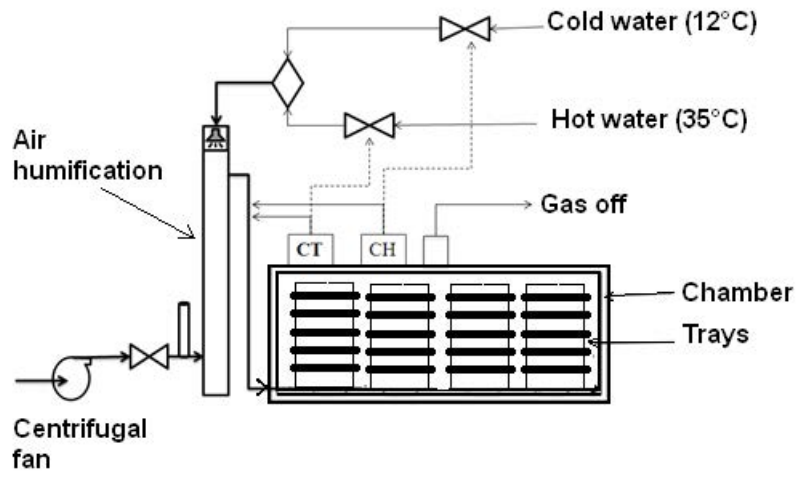

Figure 2: Schematic representation of a tray chamber with air temperature and moisture control 


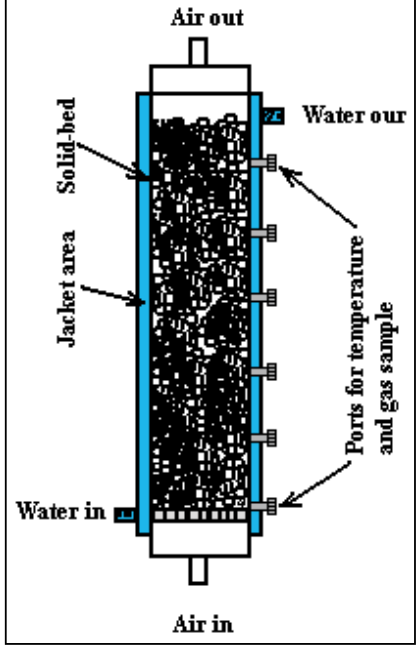

(a)

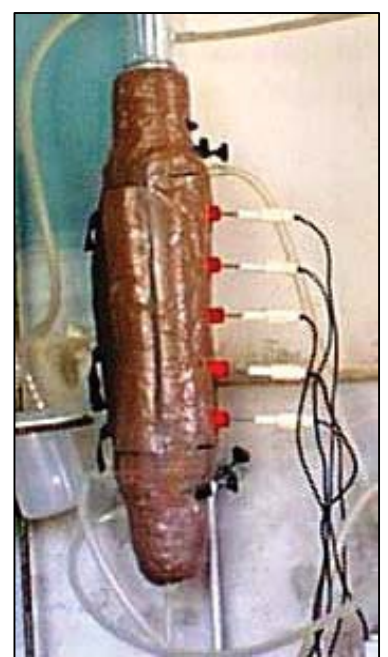

(b)
Figure 3: Packed-bed bioreactors used at different stages of process development (a) schematic representation; (b) Real lab-scale bioreactor [7]

\begin{tabular}{|c|c|c|c|c|c|}
\hline Strain & $\begin{array}{c}\text { Bioreactor } \\
\text { type }\end{array}$ & $\begin{array}{c}\text { Scale } \\
\text { (g) }\end{array}$ & $\begin{array}{c}\text { Lipase } \\
\text { activity } \\
\left(\mathbf{U g}^{-1}\right)\end{array}$ & $\begin{array}{c}\text { Time } \\
\text { (h) }\end{array}$ & References \\
\hline \multicolumn{6}{|l|}{ Yeast } \\
\hline Yarrowia lipolytica & TB & 25 & 26 & 96 & [84] \\
\hline Candida rugosa & $\begin{array}{l}\text { TB } \\
\text { TB }\end{array}$ & $\begin{array}{l}12 \\
10\end{array}$ & $\begin{array}{l}11 \\
88\end{array}$ & $\begin{array}{c}120 \\
96\end{array}$ & $\begin{array}{l}{[85]} \\
{[65]}\end{array}$ \\
\hline \multicolumn{6}{|l|}{ Mold } \\
\hline Penicillium Sp. & TB & 10 & 140 & 48 & [79] \\
\hline Penicillium simplicissimum & TB & 10 & 90 & 72 & [78] \\
\hline Penicillium chrysogenum & TB & 17 & 65 & 72 & [98] \\
\hline Aspergillus niger & $\begin{array}{l}\text { TB } \\
\text { TB } \\
\text { TB } \\
\text { TB } \\
\text { TB } \\
\text { TB }\end{array}$ & $\begin{array}{c}33 \\
20 \\
10 \\
100 \\
1000 \\
10\end{array}$ & $\begin{array}{c}1934 \\
63 \\
623 \\
598 \\
523 \\
142\end{array}$ & $\begin{array}{l}96 \\
48 \\
72 \\
72 \\
72 \\
96\end{array}$ & $\begin{array}{c}{[99]} \\
{[6]} \\
{[9]} \\
{[9]} \\
{[9]} \\
{[100]}\end{array}$ \\
\hline Rhizopus chinensis & TB & 30 & 350 & 36 & [101] \\
\hline \multirow{2}{*}{ Rhizopus homothallicus } & PBB & 20 & 826 & 12 & [102] \\
\hline & PBB & 50 & 1500 & 13 & [103] \\
\hline $\begin{array}{c}\text { Rhizopus microsporus var. } \\
\text { tuberosus }\end{array}$ & PBB & 20 & 74 & 20 & [104] \\
\hline $\begin{array}{c}\text { Rhizopus microsporus var. } \\
\text { chinensis }\end{array}$ & PBB & 20 & 72 & 20 & [104] \\
\hline \multirow{2}{*}{ Rhizopus oligosporous } & TB & 10 & 48 & 48 & {$[105]$} \\
\hline & TB & 8 & 77 & 120 & [106] \\
\hline Rhizopus oryzae & TB & 5 & 236 & 72 & {$[16]$} \\
\hline
\end{tabular}

Table 2: Lipase activity achieved in tray (TB) and packed-bed bioreactors (PBB)

$15 \mathrm{~cm}$ deep. Trays usually have an open top and perforated bottom to favor exchange with the gaseous phase. Intermittent mixing of the solid substrate by hand could be carried out but in general this will occur only once per day. The main drawback of TB is their low volumetric efficiency compared to column bioreactor [95]. Indeed, the thickness of the bed must remain low while the space between the trays must remain large enough to ensure an optimal gas and heat transfer. There have been no significant advances in tray design over the last decade.

PBB typically involves a static bed on top of a perforated plate through which conditioned air is blown (Figure 3 ). In some PBB design, air is blown through a perforated rod inserted into the center of the bed. Over the last 25 years, PBB has received much experimental and modeling attention. The main attractive characteristic is that it has no mechanical (i.e. moving) parts, thus reducing the cost of construction, operation and maintenance. In PBB processes, axial dynamical temperature profiles could be observed [96]. Since the water-carrying capacity of the air increases with temperature, these axial temperature gradients promote evaporation within the bed even if water-saturated air is used to aerate the column. Despite, this evaporation phenomenon can remove up to $65 \%$ of the heat generated by the cellular metabolism, it lowers the moisture of the solid substrate and thus limit the cellular growth [97]. In PBB, moisture regulation is almost impossible since the bed is unmixed. Therefore, it is desirable to increase heat removal by other means such as water jacket as shown in Figure 3.

In the literature, reports on large-scale production are very scarce and most of them are in the scale of few grams of solid support [11]. At small scale, comparison of the yields of lipase productions obtained for different bioreactors design is not significant. Indeed, the process at that scale is not influenced by axial temperature profiles that form within the solid substrate. Therefore, the differences in lipase productions, presented in Table 2, seem to be more dependent on strains and growth conditions than other factors. The data shown in Table 2 indicate that lipase productions are below level of $500 \mathrm{Ug}^{-1}$ in $71 \%$ of the cases while less that $10 \%$ are over $1500 \mathrm{Ug}^{-1}$. This indicates that very high productions and productivities could be reached under controlled SSF process. However at higher scale, a decrease in process productivity should be expected. Nevertheless, Edwinoliver and coll. reported only a slight decrease in lipase production when scaling up the process from $10 \mathrm{~g}$ to $1000 \mathrm{~g}$ [9].

\section{Acknowledgments}

This work was supported by WBI (Wallonie-Bruxelles International) grant SUB/2012/86836 to P. Fickers and L. B. Ramos-Sánchez.

\section{References}

1. Sarda L, Desnuelle $P$ (1958) [Actions of pancreatic lipase on esters in emulsions]. Biochim Biophys Acta 30: 513-521.

2. Verger R, De Haas GH (1973) Enzyme reactions in a membrane model. 1. A new technique to study enzyme reactions in monolayers. Chem Phys Lipids 10: 127-136.

3. Verger R (1997) 'Interfacial activation' of lipases: facts and artifacts. Trends Biotechnol 15: 32-38.

4. Rodrigues RC, Fernandez-Lafuente R (2010) Lipase from Rhizomucor miehei as an industrial biocatalyst in chemical process. J Mol Catal B: Enzymatic 64: 1-22.

5. Liu CH, Chen CY, Wang YW, Chang JS (2011) Fermentation strategies for the production of lipase by an indigenous isolate Burkholderia sp. C20. Biochem Eng J 58-59: 96-102.

6. Damaso MC, Passianoto MA, de Freitas SC, Freire DM, Lago RC, et al (2008) Utilization of agroindustrial residues for lipase production by solid-state fermentation. Braz J Microbiol 39: 676-681.

7. Thakur S (2012) Lipases, its sources, properties and applications: A Review. Int J Sci Energ Res 3: 1-29.

8. Gutarra ML, Godoy MG, Maugeri F, Rodrigues MI, Freire DM, et al. (2009) Production of an acidic and thermostable lipase of the mesophilic fungus Penicillium simplicissimum by solid-state fermentation. Bioresour Technol 100: 5249-5254.

9. Edwinoliver NG, Thirunavukarasu K, Naidu RB, Gowthaman MK, Kambe TN, et al. (2010) Scale up of a novel tri-substrate fermentation for enhanced production of Aspergillus niger lipase for tallow hydrolysis. Bioresour Technol 101: 6791-6796.

10. Hosseinpour MN, Najafpour GD, Younesi H, Khorrami M, Vaseghi Z (2012) Lipase production in solid state fermentation using Aspergillus niger. Response surface methodology. IJE Transactions B: Applications 25: 151-159. 
11. Bhargav S, Panda BP, Ali M, Javed S (2008) Solid-state fermentation: An overview. Chem Biochem Eng Q 22: 49-70.

12. Kumar A, Kanwar S (2012) Lipase production in solid-sate fermentation (SSF): Recent developments and biotechnological applications. Dynam Biochem Proc Biotecnol Mol Biol 6: 13-27.

13. Khanahmadi M, Mitchell DA, Beheshti M, Roostaazad R, Sánchez LR (2006) Continuous solid-state fermentation as affected by substrate flowpattern. Chem Eng Sci 61: 2675-2687.

14. Ramos-Sanchez LB, Khanahmadi M, Mitchell D (2006) Continuous solid-state fermentation bioreactors. Solid-state fermentation bioreactors- fundamentals of design and operation. D. A. Mitchell, N. Krieger \& M. Berovic (Editors) Springer edition, Germany 142-158.

15. Pandey A, Soccol CR, Mitchell DA (2000) New developments in solid state fermentation: I-bioprocesses and products. Proc Bioch 35: 1153-1169.

16. Vaseghi Z, Najafpour GD, Mohseni S, Mahjoub S ( 2013) Production of active lipase by Rhizopus oryzae from sugarcane bagasse: solid state fermentation in a tray bioreactor. Int J Food Sci Technol 48: 283-289.

17. Couto SR, Sanroman MA (2006) Application of solid-state fermentation to food industry-A review. J Food Eng 76: 291-302.

18. Mitchell D, Berovi M, Krieger N (2006) Introduction to solid-state fermentation bioreactors. Solid-state fermentation bioreactors-fundamentals of design and operation. Mitchell DA, Krieger N, Berovic M (Editors) Springer edition, Germany, 33-44

19. Mitchell D, Berovi M, Nopharatana M (2006) The Bioreactor Step of SSF: A Complex interaction of phenomena. Solid-state fermentation bioreactorsfundamentals of design and operation. Mitchell DA, Krieger N, Berovic M (Editors) Springer edition, Germany, 13-32.

20. Coradi GV, Visitacao VL, de Lima EA, Saito LYT, Palmieri DA, et al. (2013) Comparing submerged and solid-state fermentation of agro-industrial residues for the production and characterization of lipase by Trichoderma harzianum. Ann Microbiol 63: 533-540.

21. Rajan A, Nair AJ (2011) A comparative study on alkaline lipase production by a newly isolated Aspergillus fumigatus MTCC 9657 in submerged and solid-state fermentation using economically and industrially feasible substrate. Turkish $J$ Biol 35: 569-574.

22. Mateos Diaz JC, Rodríguez JA, Roussos S, Cordova J, Abousalham A, et al. (2006) Lipase from the thermotolerant fungus Rhizopus homothallicus is more thermostable when produced using solid state fermentation than liquid fermentation procedures. Enz Microb Technol 39: 1042-1050.

23. Nwuche CO, Aoyagi H, Ogbonna JC (2013) Lipase production from palm oil mill effiuent by Aspergillus terreus immobilized on Luffa sponge. J Appl Sci 24 5661-5671.

24. Khoramnia A, Ebrahimpour A, Beh BK, Lai OM (2011) Production of a solvent detergent, and thermotolerant lipase by a newly isolated Acinetobacter sp. in submerged and solid-state fermentations. J Biomed Biotechnol 2011: 702179.

25. Godoy MG, Gutarra ML, Castro AM, Machado OL, Freire DM (2011) Adding value to a toxic residue from the biodiesel industry: production of two distinct pool of lipases from Penicillium simplicissimum in castor bean waste. $\mathrm{J}$ Ind Microbiol Biotechnol 38: 945-953.

26. Casas-Godoy L, Duquesne S, Bordes F, Sandoval G, Marty A (2012) Lipases: an overview. Methods Mol Biol 861: 3-30.

27. Aravindan R, Anbumathi P, Viruthagiri T (2007) Lipase applications in food industry. Indian J Biotechnol 6: 141-158.

28. Fickers P, Marty A, Nicaud JM (2011) The lipases from Yarrowia lipolytica: genetics, production, regulation, biochemical characterization and biotechnological applications. Biotechnol Adv 29: 632-644.

29. Erik B, Steinborn G, Florsch K (2009) Yeast Biotechnology: Diversity and Applications. Yeast Biotechnol Div Appl: 323-355.

30. Ray A (2012) Application of Lipase in Industry. Asian J Pharm Tech 2: 33-37.

31. Lock LL, Corbellini VA, Valente P (2007) Lipases produced by yeasts: Powerful biocatalysts for industrial purposes. Tecno-Logica 11: 18-25.

32. Tanino T, Aoki T, Chung WY, Watanabe Y, Ogino C, et al. (2009) Improvement of a Candida antarctica lipase B-displaying yeast whole-cell biocatalyst and its application to the polyester synthesis reaction. Appl Microbiol Biotechnol 82: 59-66.
33. Akoh CC (1993) Lipase-catalyzed synthesis of partial glyceride. Biotechnol Let 15: $949-954$

34. Bakirci H, Li M, He B (1995) Immobilization of Candida cylindracea lipase on methyl acrylate-divinyl benzene copolymer and its derivatives. Enz Microb Technol 17: 194-199.

35. Schmid R, Verger R (1998) Lipasen: Grenzflächen-Enzyme mit attraktiven Anwendungen. Ang Chemie 110: 1694-1720.

36. Pierce G, Wick C, Palmer D (1990) Unique microbial lipases with activity at temperatures and pHs suitable for use in detergents. EP $0385401 \mathrm{~A} 1$.

37. Hasan F, Shah AA, Javed S, Hameed A (2010) Enzymes used in detergents: lipases. J Biotechnol 9: 4836-4844.

38. Vakhlu J, Kour A (2006) Yeast lipases: enzyme purification, biochemical properties and gene cloning. Elect J Biotechnol 9: 69-85.

39. Pandey A, Benjamin S, Soccol CR, Nigam P, Krieger N, et al. (1999) The realm of microbial lipases in biotechnology. Biotechnol Appl Biochem $29: 119-131$.

40. Larios A, García HS, Oliart RM, Valerio-Alfaro G (2004) Synthesis of flavor and fragrance esters using Candida antarctica lipase. Appl Microbiol Biotechnol 65 373-376.

41. Shay LK, Fisher TJ (1990) Enhancing the flavor of protein products derived from microorganisms. EP Patent US $5071762 \mathrm{~A}$

42. Hasan F, Shah AA, Hameed A (2006) Industrial applications of microbial lipases. Enz Microbial Technol 39: 235-251.

43. Sharma D, Sharma B, Shukla AK (2011) Biotechnological approach of microbial lipase: A Review. Biotechnology 10: 23-40.

44. Johnson EA1 (2013) Biotechnology of non-Saccharomyces yeasts-the basidiomycetes. Appl Microbiol Biotechnol 97: 7563-7577.

45. Yücel S, Terzioglu P, Özçimen D (2012) Lipase applications in biodiese production. Biodiesel-feedstocks, production and application. InTech Publishers, Croatia.

46. Matsumae H, Furui M, Shibatani T (1993) Lipase-catalyzed asymmetric hydrolysis of 3-phenylglycidic acid ester, the key intermediate in the synthesis of diltiazem hydrochloride. J Ferm Bioeng 75: 93-98.

47. Hsu AF, Jones K, Foglia TA, Marmer WN (2002) Immobilized lipase-catalysed production of alkyl esters of restaurant grease as biodiesel. Biotechnol Appl Biochem 36: 181-186.

48. Verma N, Thakur S, Bhatt AK (2012) Microbial Lipases: Industrial Applications and Properties (A Review). Int Res J Biol Sci 1: 88-92.

49. Abada EA (2008) Production and characterization of a mesophilic lipase isolated from Bacillus stearothermophilus AB-1. Pak J Biol Sci 11: 1100-1106.

50. Dutra JC, da C Terzi S, Bevilaqua JV, Damaso MC, Couri S, et al. (2008) Lipase production in solid state fermentation monitoring biomass growth of Aspergillus niger using digital image processing. Appl Biochem Biotechnol 147: 63-75.

51. Fickers P, Nicaud JM, Gaillardin C, Destain J, Thonart P (2004) Carbon and nitrogen sources modulate lipase production in the yeast Yarrowia lipolytica. $J$ Appl Microbiol 96: 742-749.

52. Fickers P, Fudalej F, Nicaud JM, Destain J, Thonart P (2005) Selection of new over-producing derivatives for the improvement of extracellular lipase production by the non-conventional yeast Yarrowia lipolytica. J Biotechnol 115 379-386.

53. Destain J, Fickers P, Weekers F, Moreau B, Thonart P (2005) Utilization of methyloleate in production of microbial lipase. Appl Biochem Biotechnol 121124: $269-77$

54. Fickers P, Nicaud JM, Destain J, Thonart P (2003) Overproduction of lipase by Yarrowia lipolytica mutants. Appl Microbiol Biotechnol 63: 136-142.

55. Turki S, Kraeim IB, Weeckers F, Thonart P, Kallel H (2009) Isolation of bioactive peptides from tryptone that modulate lipase production in Yarrowia lipolytica. Bioresour Technol 100: 2724-2731.

56. Farias MA, Valoni EA, Castro AM, Coelho MAZ (2014) Lipase production by Yarrowia lipolytica in solid state fermentation using different agro industrial residues. Chem Eng Trans 38: 301-306.

57. del Rio JL, Serra P, Valero F et al. (1990) Reaction scheme of lipase production by Candida rugosa growing on olive oil. Biotechnol Lett 12: 835-838. 
58. de María PD, Sánchez-Montero JM, Alcántara AR, Valero F, Sinisterra JV (2005) Rational strategy for the production of new crude lipases from Candida rugosa. Biotechnol Lett 27: 499-503.

59. Wei D, Zhang LY, Song Q (2004) Studies on a novel carbon source and cosolvent for lipase production by Candida rugosa. J Ind Microbiol Biotechnol 31: $133-136$

60. Ferrer $\mathrm{P}$, Montesinos JL, Valero F, Solà C (2001) Production of native and recombinant lipases by Candida rugosa: a review. Appl Biochem Biotechnol 95: 221-255.

61. Ota Y, Miyairi S, Yamada K (1968) Sterol requirements for the lipase production by Candida cylindracea. Agric Biol Chem 32: 1476-1478.

62. Lakshmi BS, Kangueane P, Abraham B, Pennathur A (1999) Effect of vegetable oils in the secretion of lipase from Candida rugosa (DSM2031). Let Appl Microbiol 29: 66-70.

63. Alcantara AR, de Maria PD, Fernandez M, Hernaiz MJ, Montero S, et al. (2004) Resolution of racemic acids, esters and amines by Candida rugosa lipase in slightly hydrated organic medium. Food Technol Biotechnol 42: 343-354.

64. Korbekandi H, Abedi D, Pourhossein M, Motovali-Bashi M (2008) Optimisation of Candida rugosa lipase esterase activity. Biotechnology 7: 112-117.

65. Benjamin S, Pandey A (1997) Coconut cake-a potent substrate for the production of lipase by Candida rugosa in solid-state fermentation. Acta Biotechnologica 17: 241-251.

66. Rajendran A, Palanisamy A, Thangavelu V (2008) Evaluation of medium components by Plackett-Burman statistical design for lipase production by Candida rugosa and kinetic modeling. Sheng Wu Gong Cheng Xue Bao 24 436-444.

67. Kamini NR, Mala JGS, Puvanakrishnan R (1998) Lipase production from Aspergillus niger by solid-state fermentation using gingelly oil cake. Process Biochem 33: 505-511.

68. Sarkar D, Laha S (2013) Optimization of extracellular lipase enzyme production from Aspergillus niger by submerged and solid-state fermentation process. Int J Pharm Bio Sci 4: 978-985.

69. Kaushik R, Saran S, Isar J, Saxena RK (2006) Statistical optimization of medium components and growth conditions by response surface methodology to enhance lipase production by Aspergillus carneus. J Mol Catal B: Enz 40: 121-126.

70. Yadav RP, Saxena RK, Gupta R, Davidson S (1998) Lipase production by Aspergillus and Penicillium species. Folia Microbiol (Praha) 43: 373-378.

71. Ohnishi K, Yoshida Y, Sekiguchi J (1994) Lipase production of Aspergillus oryzae. J Ferment Bioing 77: 490-495.

72. Elibol M, Ozer D (2000) Influence of oxygen transfer on lipase production by Rhizopus arrhizus. Process Biochem 36: 325-329.

73. Khayati G, Kiyani F (2012) A statistical approach for optimization of lipase production by using rice straw: analysis of different inducers and nitrogen sources effect. Minerva Biotechnol 24: 83-89.

74. Gombert AK, Pinto AL, Castilho LR, Freire DMG (1999) Lipase production by Penicillium restrictum in solid-state fermentation using babassu oil cake as substrate. Proc Bioch 35: 85-90.

75. Silva MF, Freire DM, de Castro AM, Di Luccio M, Mazutti MA, et al. (2011) Production of multifunctional lipases by Penicillium verrucosum and Penicillium brevicompactum under solid state fermentation of babassu cake and castor meal. Bioprocess Biosyst Eng 34: 145-152.

76. Liu CH, Lu WB, Chang JS (2006) Optimizing lipase production of Burkholderia $\mathrm{sp}$. by response surface methodology. Process Biochem 41: 1940-1944.

77. Miranda OA, Salgueiro AA, Pimentel MCB, Filho JLL, Melo EHM, et al. (1999) Lipase production by a Brazilian strain of Penicillium citrinum using an industrial residue. Biores Technol 69: 145-147.

78. Gutarra ML, Cavalcanti ED, Castilho LR, Freire DM, Sant'Anna GL (2005) Lipase production by solid-state fermentation: cultivation conditions and operation of tray and packed-bed bioreactors. Appl Biochem Biotechnol 121124: $105-16$

79. Rigo E, Ninow JL, Di Luccio M, Vladimir Oliveira J, Polloni AE, et al. (2010) Lipase production by solid fermentation of soybean meal with different supplements. LWT- Food Sci Technol 43: 1132-1137.
80. Rao PV, Jayaraman K, Lakshmanan CM (1993) Production of lipase by Candida rugosa in solid-state fermentation. I: determination of significant process variables. Proc Biochem 28: 385-389.

81. Cordova J, Nemmaoui M, Ismaili-Alaoui M, Morin A, Roussos S, et al. (1998) Lipase production by solid state fermentation of olive cake and sugar cane bagasse. J Mol Catal B: Enz 5: 75-78.

82. Mahadik ND, Puntambekar US, Bastawde KB et al. (2002) Production of acidic lipase by Aspergillus niger in solid state fermentation. Proc Biochem 38: 715-721.

83. Mahanta N, Gupta A, Khare SK (2008) Production of protease and lipase by solvent tolerant $P$ seudomonas aeruginosa PseA in solid-state fermentation using Jatropha curcas seed cake as substrate. Bioresour Technol 99: 1729-1735.

84. Imandi SB, Karanam SK, Garapati HR (2014) Use of Plackett-Burman design for rapid screening of nitrogen and carbon sources for the production of lipase in solid state fermentation by Yarrowia lipolytica from mustard oil cake (Brassica napus). Braz J Microbiol 44: 915-921.

85. Rekha K, Lakshmi M, Sridevi V (2012) An overview of microbial lipases. J Chem Biol Phys Sci 2: 1379-1389.

86. Imandi SB, Karanam SK, Garapati HR (2014) Use of Plackett-Burman design for rapid screening of nitrogen and carbon sources for the production of lipase in solid state fermentation by Yarrowia lipolytica from mustard oil cake (Brassica napus). Braz J Microbiol 44: 915-921.

87. Imandi SB, Karanam SK, Garapati HR (2010) Optimization of media constituents for the production of lipase in solid state fermentation by Yarrowia lipolytica from palm Kernal cake (Elaeis guineensis). Adv Biosci Biotechnol 1 : 115-121.

88. Gervais P, Molin P (2003) The role of water in solid-state fermentation. Biochem Eng J 13: 83-110.

89. Rocha NRAF, Barros MA, Fisher J, Filho UC, Cardoso VL (2013) Ethano production from agroindustrial biomass using a crude enzyme complex produced by Aspergillus niger. Renew Energ 57: 432-435.

90. Babu I, Rao G (2007) Lipase production by Yarrowia lipofyäca NCIM 3589 in solid state fermentation using mixed substrate. Res J Microbiol 2: 469-474.

91. Krishna C1 (2005) Solid-state fermentation systems-an overview. Crit Rev Biotechnol 25: 1-30.

92. Pandey A (2003) Solid-state fermentation. Biochem Eng J 13: 81-84.

93. Ali H, Zulkali MMD (2011) Utilization of agro-residual ligno-cellulosic substances by using solid state fermentation: A review. Croatian J Food Technol Biotechnol Nut 6: 5-12.

94. Vaseghi Z, Najafpour GD (2014) An Investigation on lipase production from soybean meal and sugarcane bagasse in solid state fermentation using Rhizopus oryzae. IJE Trans B: Applications 27: 171-176.

95. Mirón J, Vázquez J, González P, Murado MA (2010) Enhancement glucose oxidase production by solid-state fermentation of Aspergillus niger on polyurethane foams using mussel processing wastewaters. Enz Microb Technol 46: 21-27.

96. Ashley VM, Mitchell DA, Howes T (1999) Evaluating strategies for overcoming overheating problems during solid state fermentation in packed bed bioreactors. Biochem Eng J 3: 141-150.

97. Gutierrez M, Amar S, Auria R, Revah S, Torres EF (1996) Heat transfer in citric acid production by solid state fermentation. Proc Biochem 31: 363-369.

98. Iftikhar T, Niaz M, Nisa Z, Tariq A, Khalid MN, et al. (2011) Optimization of cultural conditions for the biosynthesis of lipases by Penicillium chrysogenum (MBL 22) through solid state fermentation. Pak J Bot 43: 2201-2206.

99. Adinarayana K, Raju KVVSN, Zargar MI, Bhavani DR, Jhansi LP, et al. (2004 Optimization of process parameters for production of lipase in solid-state fermentation by newly isolated Aspergillus species. Ind J Biotechnol 3: 65-69.

100. Mohseni S, Najafpour G, Vaseghi Z, Mahjoub S (2012) Solid state fermentation of agricultural residues for lipase production in a tray-bioreactor. World Appl Sci J 16: 1034-1039.

101. Sun SY, Xu Y (2008) Solid-state fermentation for "whole-cell synthetic lipase"production from Rhizopus chinensis and identification of the functional enzyme. Process Biochem 43: 219-224. 
Citation:Ramos-Sanchez LB, Cujilema-Quitio MC, Julian-Ricardo MC, Cordova J, Fickers P (2015) Fungal Lipase Production by Solid-State Fermentation. J Bioprocess Biotech 5: 203 doi:10.4172/2155-9821.1000203

102. Rodriguez JA, Mateos JC, Nungaray J, Gonzalez V, Bhagnagar T, et al. (2006) Improving lipase production by nutrient source modification using Rhizopus homothallicus cultured in solid state fermentation. Process Biochem 41: 2264-2269.

103. Diaz JC, Rodríguez JA, Roussosb S, Cordovac J, Abousalhamd A, et al. (2006) Lipase from thermotolerant fungus Rhizopus homothalicus is more stable when produced using solidstate fermentation than in liquid fermentation procedures. Enz Microb Technol 39: 1042-1050.
104. Hernández B, Córdova J, Bárzana E, Favela E (2009) Effects of organic solvents on activity and stability of lipases produced by thermotolerant fung in solid-state fermentation. J Mol Catal B Enz 61: 136-142.

105. Ul-Haq I, Idrees S, Rajoka M (2002) Production of lipase by Rhizopus oligosporous by solid state fermentation. Process Biochem 37: 637-641.

106. Mahapatra P, Kumari A, Garlapati VK, Banerjee R, Nag A (2010) Optimization of Process Variables for Lipase Biosynthesis from Rhizopus oligosporus NRRL 5905 Using Evolutionary Operation Factorial Design Technique. Indian J Microbiol 50: 396-403. 